\title{
PSYCHE
}

\begin{tabular}{lll}
\hline Vol. 95 & 1988 & No. 1-2 \\
\hline
\end{tabular}

\section{TRAIL PATTERNS AND MOVEMENT OF WORKERS AMONG NESTS IN THE ANT FORMICA OBSCURIPES (HYMENOPTERA: FORMICIDAE)*}

\author{
By Kevin M. O’Neill \\ Department of Entomology, \\ Montana State University, \\ Bozeman, Montana 59717
}

\begin{abstract}
INTRODUCTION
In ants of the genus Formica, intraspecific interactions among workers from different nest mounds vary from mutual tolerance to aggression and territoriality. For example, workers of Formica opaciventris and $F$. ulkei commonly visited nearby nests without evoking agonistic responses (Scherba, 1964; Talbot, 1961). On the other hand, in a study of a British population of $F$. rufa, workers engaged in aggressive territorial contests with workers from nearby mounds (Skinner, 1980). Both aggressive and non-aggressive interactions have been observed within populations of $F$. rufa in Russia (Marikovsky, 1962) and $F$. polyctena (Mabelis, 1979a, b). This is not surprising, since Formica populations may consist of separate colonies, some of which have multiple nests (i.e. polydomous colonies; Pamilo et al., 1978; Wilson, 1971). The elucidation of patterns of interactions among workers from different nest mounds is essential for an understanding of the genetic organization of populations (Pamilo, 1981, 1982; Pamilo et al., 1978), the social structure and spatial dispersion of colonies, and the proximate factors influencing the form of intraspecific interactions among ants. Such interactions are apparently influenced by the recent history of nest founding and
\end{abstract}

*Manuscript received by the editor February 2, 1988. 
nest splitting in a population which defines the spatial correlates of relatedness among nests and colonies (Mabelis, 1979a, b; Pamilo, 1981) and may be regulated by the patterns of foraging trails (Hölldobler, 1974, 1976; Hölldobler and Lumsden, 1980; Skinner, 1980; Brian, 1983). Competition among ant colonies for limited resources may also play a role in defining the nest distribution (Levings and Traniello, 1981; Ryti and Case, 1986) and nature of interactions (Mabelis, 1979b; Skinner, 1980).

Formica obscuripes Forel is a common ant of the northcentral and western United States, where it constructs mound nests covered with twigs, grass stems, and other plant material. Nests are connected to foraging areas via a system of permanent trails over which foragers return to nests with honeydew, prey, and carrion (Weber, 1935). This paper reports the results of a study of the pattern of trails among a group of 45 nest mounds and the movement of workers among nests in relation to trail location in $F$. obscuripes. Here, the term "nest" refers simply to a distinct above ground mound, without implying that each mound represents a discrete colony.

\section{Materials AND MethodS}

Formica obscuripes was studied at a site along an unused railroad track near the outskirts of Bozeman, MT from 16 June through 11 September, 1986. There were 45 nests active during the study period. Twenty-nine were chosen for more careful study. A map of the study site was constructed to include the location of all of the nests, trails used by the worker ants, and the major patches of plants visited by the ants. The site was surveyed at least once per week for the presence of new trails and nests. The mounds of plant material constituting the above ground portion of nests of $F$. obscuripes at the research site ranged in height from four to $33 \mathrm{~cm}$ (mean =9.9; $\mathrm{SD}=7.8 ; \mathrm{N}=29$ ) with the maximum width of mounds ranging from 15 to $130 \mathrm{~cm}($ mean $=54.9 ; \mathrm{SD}=28.8 ; \mathrm{N}=29)$. Since there were few plants growing on nests, the mounds were conspicuous. Thus, it is likely that all of the mounds within the research site were located.

To determine the movement patterns of workers, a large number were marked using two different techniques: 1) between 17 July and 18 August, 1300 workers from five nests were marked on the dor- 
sum of the abdomen with dots of colored enamel paint; 2) a larger sample of unknown size was marked by spraying the surface of active nests with a fine mist of enamel paint, applying minute spots of paint to the surface of the ants. Workers ants marked in this manner continued to work on the nest surface and forage for the remainder of the season. This indicates that this marking technique did not have an adverse effect upon most workers. At least three of these workers were still present on nests on 15 March, 1987. Ants from nine nests were marked using these methods, allowing me to later determine the distance that many of the ants moved from the original location at which they were observed.

Nest census techniques were modified from those of Scherba (1964). After tapping the surface of the nest to arouse the workers, all marked workers appearing over the next two minutes were counted, removed, and killed. This was done once each day on nine days between 25 August and 11 September. The study was terminated at this time because the railroad company had the tracks removed on 14 September. This destroyed many of the nests and disrupted much of the system of trails between the remaining nests. Censuses were conducted only before 1000 hours or after 1700 hours, since workers did not remain on the nest in the middle of the day when surface temperatures were high (O'Neill and Kemp, unpublished). In the results, a single "crossover" refers to the recapture, on a censused nest, of one or more workers originally marked on another nest. Thus, if five workers marked on nest \#6 were later recaptured on nest \#11, this is recorded as a single crossover.

To determine whether workers on a nest would tolerate the presence of workers from other nests, an experiment was conducted in which workers were transferred between nests. The experimental group consisted of 40 workers collected on the surface of nests and transferred individually to other nests, not connected via a trail to the nest on which they were captured. As a control, 30 workers were moved between nests connected to one another via a trail system. A second control consisted of 5 workers removed from the surface of a nest and returned to the surface of the same nest. Each ant was handled only with a pair of forceps that had just been washed with ethylene chloride and air dried. After introduction to the surface of the nest, the worker was monitored until ten workers from the nests had made contact with it; during this period I recorded whether or not it was attacked by workers present on the nest surface. 


\section{RESULTS}

Trail pattern: Trails of Formica consisted primarily of permanent pathways used by ants to travel from nests to foraging areas and to other nests. The workers foraged for at least two types of resources. They visited plants in the area that had populations of honeydewsecreting Homoptera. These included several species of aphids (Aphididae) and two species of Membracidae (Campylenchia latipes Say and Publilia modesta (Uhler)). They also foraged on and near trails for dead and living arthropods. The major items being carried by workers to nests along trails included terrestrial isopods (Crustacea: Oniscoidea), various species of leafhopper (Homoptera: Cicadellidae), Lepidoptera larvae, and workers of other species of ants, especially Formica neoclara Emery. Workers of $F$. obscuripes were observed to prey upon workers of $F$. neoclara on at least a dozen occasions. Nests of the latter species were sometimes within a meter of nests of F. obscuripes.

The major trails (Figure 1) remained active throughout the study period. The trails coming from the nests led to 1) concentrations of Homoptera on Canada thistle (Cirsium arvense), chokecherry (Prunus virginiana), and several other species of plants and 2) other nests (Figure 1). Five non-overlapping systems of trails (labelled A through D in Figure 1) that intersected 32 of 45 nests were identified at the study site. The longest trail system (A), consisting of two long parallel trails and branches leading from them, followed an old railway bed and served 23 nests (nest group A). The other trail systems, within nest groups B through E, served two, three, two, and two nests, respectively. Six of the 13 nests for which no trails were observed became inactive by the end of the study period; all other nests remained active throughout. Only two short sections of trail (i.e. one between nests \#4 and \#6 and another crossing the railway bed near nest \#6; Figure 1) disappeared during the course of the study. Both had been abandoned at least one month before the censusing began.

Worker movement: Workers were marked on eight nests from group A. In nine surveys (sampling without replacement) of 29 nests in the area made on nine days between 25 August and 11 September, 1986 , ants from these eight nests were found to make $88(39 \%)$ of a possible 224 different crossovers to other nests. A total of 405 workers were recaptured on nests other than those on which they 


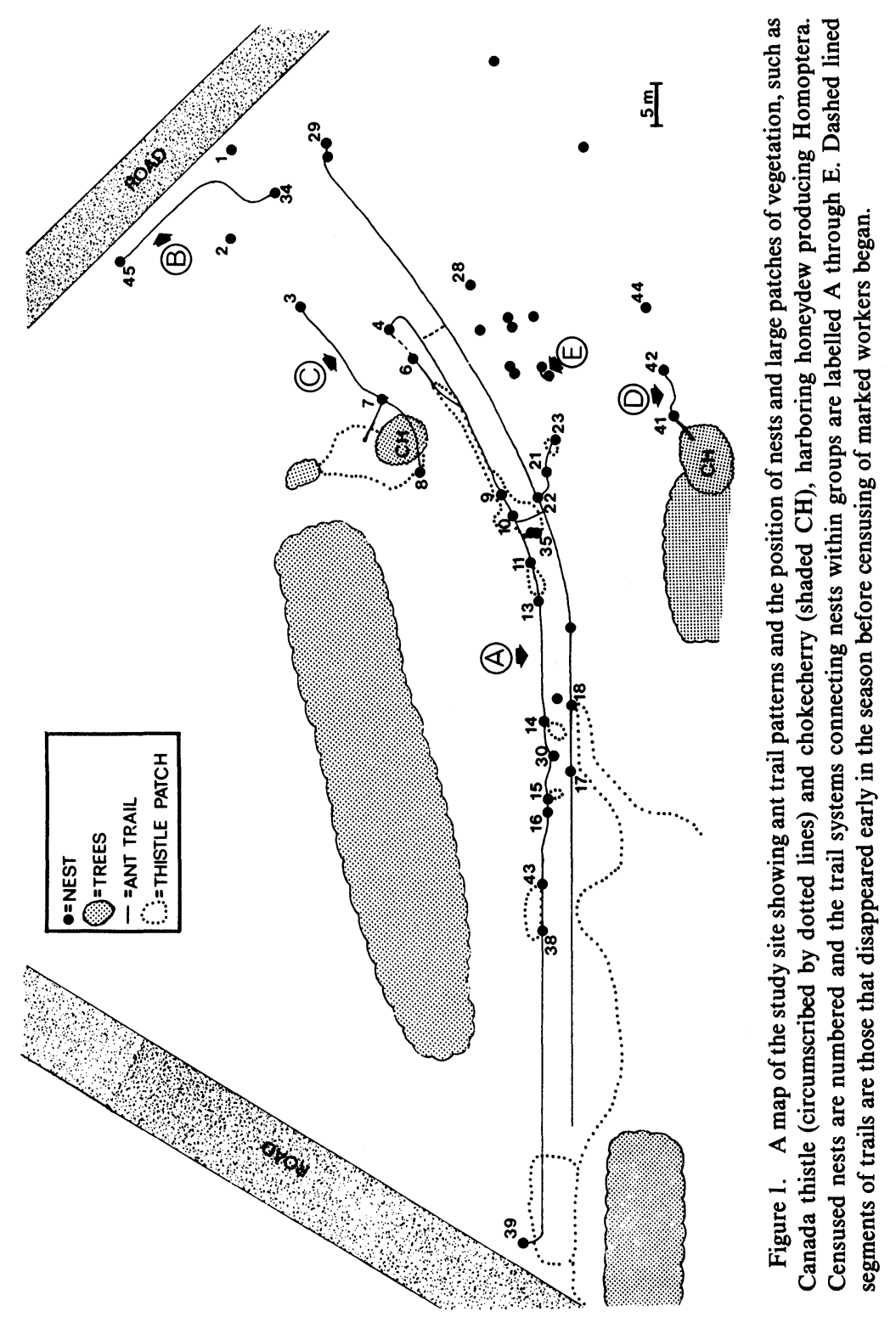


were marked. Marked ants observed on nests were moving about without interference from other ants present. On five occasions, ants marked on other mounds were observed entering nests. Workers often travelled great distances between nests. For example, the worker from nest \#4 found on \#39 would have had to traverse over $120 \mathrm{~m}$ of trail between the two nests, which were about $112 \mathrm{~m}$ apart.

Although there was considerable movement of workers among nests, the pattern of crossovers was non-random. The nest censusing described above included nests that were not connected to each other via trails. While all of the ants were marked on nest group A, only 20 of the surveyed nests were within this group. Of the remaining nine, one ( $\# 34)$ was in group $B$, three $(\# 3, \# 7$, and $\# 8)$ were in group $\mathrm{C}$, two (\#41 and \#42) were in group $\mathrm{D}$, and three (\#1, \#2, and $\# 28$ ) were not connected by trails to other nests during the course of the study. Ants marked on nests in group A were rarely found on nests of other groups (Table 1). Of the 88 different crossovers noted above, 86 were between nests within group $\mathrm{A}$. The exceptions were an individual from nest \#4 found on nests \#7 and two from nest \#29 found on \#28. Thus, fewer than $1 \%$ of the 405 marked ants recaptured on nests other than those on which they were marked were found on nests outside of group A. Apparently, workers from nests in group A rarely mingled with those from other trail systems, possibly because they do not travel the distances separating different trail systems or because workers will not tolerate the presence of workers from other colonies.

Crossovers among nests within group A were also non-random. The movement of workers among nests was asymmetrical. For example, while only two workers from other nests were seen on nest $\# 29,142$ marked workers from \#29 were found on 14 other nests (67\% of those censused). The opposite was true of nest \#11: 68 workers from seven other nests were found on this nest, while only 13 workers from \#11 were found on seven other nests (33\% of those censused). In addition, marked workers did not distribute themselves evenly among nests to which they had transferred. For example, of the 142 workers from nest \#29 found on 14 other nests, 121 (85\%) were found on just five of these mounds.

Out of the total of 1300 ants marked with single dots of paint on the abdomen (described in methods section as marking procedure $\# 1), 313$ (42\%) were recovered in the nine subsequent surveys. Of 
Table 1. The number of different crossovers (i.e. where at least one marked individual from a nest was found on censused nest) and the number of marked workers observed during censuses. All workers were originally marked on one of eight nests in group A. Comparison on different crossovers within group A to those from group $\mathrm{A}$ to other censused nests (i.e. row 5 vs. row 6 ), $\chi_{1}^{2}=36.0, \mathrm{P}<0.001$.

\begin{tabular}{|c|c|c|c|c|c|}
\hline \multirow[b]{2}{*}{$\begin{array}{l}\text { Censused Nest } \\
\text { Group (\# nests) }\end{array}$} & \multicolumn{3}{|c|}{ Different Crossovers } & \multicolumn{2}{|c|}{$\begin{array}{c}\text { \# Workers } \\
\text { Crossing Over }\end{array}$} \\
\hline & Observed & Possible & $\%$ & Observed & $\begin{array}{c}\text { Mean \#/ } \\
\text { Nest }\end{array}$ \\
\hline Group B (1) & 1 & 8 & 12.5 & 1 & 1.0 \\
\hline Group C (3) & 0 & 24 & 0 & 0 & 0 \\
\hline Group D (2) & 0 & 16 & 0 & 0 & 0 \\
\hline $\begin{array}{r}\text { Others not in } \\
\text { Groups (3) }\end{array}$ & 1 & 24 & 4.2 & 2 & 0.7 \\
\hline $\begin{array}{l}\text { SUBTOTAL } \\
\text { (Non-Group A) (9) }\end{array}$ & 2 & 72 & 2.8 & 3 & 0.3 \\
\hline Group A (20) & 86 & 152 & 56.6 & 402 & 20.1 \\
\hline Overall Total & 88 & 224 & 39.3 & 405 & 14.0 \\
\hline
\end{tabular}

these, $152(49 \%)$ were found on nests other than those on which they were marked (Table 2).

Lack of tolerance of ants from one nest group for ants of another was demonstrated in experiments in which ants were transferred between nests. Ants taken from distant nests and placed on nests in group A were always vigorously attacked by workers on the surface of nests (rows 1 and 2 of Table 3). Attacking ants attempted to bite and seize the intruder with their mandibles and often succeeded in dragging the intruder into the nest. This was essentially the same type of aggressive response to alien workers reported for Formica fusca (Wallis, 1962). Intruders were sometimes attacked within several seconds, with as many as six attackers eventually surrounding them. A similar result was found when ants from groups A and C were switched between groups (row 3). On the other hand, ants in control manipulations were not attacked (rows 4-6).

Observations on a section of the trail near nest \#6 (Figure 1) showed that ants marked on other nests in the same nest group (A) brought dead arthropods and honeydew to this nest. In 51 ten minute censuses on 14 days between 21 July and 20 August, 52 marked ants were carrying liquid (probably honeydew) to the nest (i.e. they had extremely distended abdomens and regurgitated liquid when 
Table 2. A comparison of the number of marked workers from five nests that were recaptured on the nest on which they were marked with the number found on other nests.

\begin{tabular}{lccc}
\hline $\begin{array}{l}\text { Nest that ant } \\
\text { was marked on } \\
\text { (total released) }\end{array}$ & $\begin{array}{c}\text { Number recaptured } \\
\text { on nest on which } \\
\text { ant was marked }\end{array}$ & $\begin{array}{c}\text { Number recaptured } \\
\text { on other nests }\end{array}$ & $\begin{array}{c}\text { Total } \\
\text { recaptured }\end{array}$ \\
\hline Number 4 (200) & 8 & 22 & 30 \\
Number 7 (250) & 29 & 18 & 47 \\
Number 11 (200) & 10 & 13 & 23 \\
Number 15(300) & 75 & 66 & 141 \\
Number 21 (350) & 39 & 33 & 72 \\
\hline Total (1300) & 161 & 152 & 313 \\
\hline
\end{tabular}

squeezed slightly) and seven carried dead arthropods. Of these, 20 (34\%) had been originally marked on other nests of group A (i.e. nests $4,9,10$, and 11). During the same censuses, none of the 72 marked ants (including 31 from other nests) moving away from nest \#6 were obviously replete with honeydew or were carrying arthropod carrion or prey. Thus, traffic of successful foragers occurred in only one direction along this trail (i.e. towards nest \#6) and included foragers originally seen on other nests. However, workers transporting live ant larvae were seen travelling along trails in both directions near nest \#6 and elsewhere in the manner described for $F$. polyctena (Mabelis, 1979a).

The data above support the conclusion that nests of group A form a group of physically inter-connected (i.e. by trails) and, possibly, functionally integrated nests. Workers were rarely found on nests of other groups and did not tolerate the presence of workers from distant nests. However, an absolute barrier did not exist between nests not connected by trails. As noted above, one worker from nest $\# 4$ was active on the surface of nest \#7 and two from nest \#29 were on \#28, apparently being tolerated by other workers. Furthermore, some of the 250 workers marked on nest $\# 7$ (group C) were recaptured either on nests of group A (11 observations during the nine censuses) or on the trail system of group A ( 3 observations during the censuses of trail near nest \#6). Most (36) of the recaptured workers from nest $\# 7$, were found on nests of group $\mathrm{C}$.

\section{Discussion}

The data reported here indicate that movement of workers among nest mounds in the local population $F$. obscuripes was non-random, 
Table 3. Results of introduction of worker ants to the surface of nests. Each was handled only with a pair of clean forceps and was watched for $30 \mathrm{~s}$ after being in introduced.

\begin{tabular}{lcccc}
\hline Manipulation & $\begin{array}{c}\text { \# ants } \\
\text { tolerated }\end{array}$ & $\begin{array}{c}\text { \# ants } \\
\text { attacked }\end{array}$ & Total & \% Attacked \\
\hline $\begin{array}{l}\text { Moved from site 15 km away } \\
\text { to nests of group A }\end{array}$ & 0 & 10 & 10 & 100 \\
$\begin{array}{l}\text { Moved from site 1 km away } \\
\text { to nests of group A }\end{array}$ & 0 & 10 & 10 & 100 \\
$\begin{array}{l}\text { Moved between nests of } \\
\text { group A and group D }\end{array}$ & 4 & 16 & 20 & 80 \\
$\begin{array}{l}\text { Within nest group switches: } \\
\text { group A }\end{array}$ & 20 & 0 & 20 & 0 \\
$\begin{array}{l}\text { Within nest group switches: } \\
\text { group D }\end{array}$ & 10 & 0 & 10 & 0 \\
$\begin{array}{l}\text { Sham switches (ant picked } \\
\text { up and returned to } \\
\text { same nest) }\end{array}$ & 5 & 0 & 5 & 0 \\
\hline
\end{tabular}

both within and between nest groups. The vast majority of workers found to move to other nests were recaptured within the same nest group: $99 \%$ of workers from group A that were recaptured and $77 \%$ of workers from group $\mathrm{C}$ that were recaptured. This occurred even though the absolute distance between nest groups was often much less than the distance between given nest pairs that exchanged workers within a group. For example, while the distance moved by workers within group A was often greater than $\mathbf{5 0}$ meters, they were rarely found to leave the nest group and join nests of other groups that were sometimes just several meters away from the trail system. Within nest groups, a mound did not always receive the same number of marked workers that were found to move from it to other nests. Furthermore, marked workers moving off of a nest did not distribute themselves evenly among other nests within a nest group. As indicated by occasional recapture of marked ants on nests outside of their "home" nest group (Table 1) and the results of experiments transferring workers between nests in groups A and D (Table 3 , row 3), the barrier between nest groups was not absolute. This suggests, perhaps, that territoriality in these ants is expressed as a graded effect, with tolerance for conspecifics from other colonies decreasing with distance or the duration of time passed since two 
mounds had a common ancestor (Mabelis, 1979b). However, further data are needed to confirm this for $F$. obscuripes.

Discussion of several limitations of the data are in order. First, as noted by Scherba (1964) the census techniques used produced only minimum estimates of crossover of marked workers among nests, since only a limited number of censuses were conducted. Second, workers captured from a nest for marking did not necessarily develop within that nest. The data reported here provide evidence for worker movement among mounds, but not an absolute picture of the pattern of switching among nests. For example, if all workers marked on nest \#6 did not originate in that nest, their recapture on nest \#11 does not indicate the exact proportion of workers making the switch from nest \#6 to nest \#11. In fact, we could reverse our interpretation of the mark-recapture data: perhaps workers captured on a nest for marking developed in the mound on which they were subsequently recaptured. This also means that the data do not allow us to determine whether workers originating in one nest eventually acted as foragers for other nests. Finally, since the majority of the workers marked were probably foragers rather nest workers, the percentage of ants found to cross over is probably an overestimate, since the latter are probably more philopatric.

In the absence of such information as the recent history of nest splitting (Mabelis, 1979a, b) and degrees of relatedness among nests and colonies (Pamilo, 1981, 1982), the pattern of worker movement observed remains descriptive. However, the data indicate that, in this population, some colonies of $F$. obscuripes are polydomous. This matches observations from an earlier study of this species in which Weber (1935) found "secondary nests... generally connected by a well-defined runway to the main nest". Since the history of the population in the present study is unknown, the parent ("main") nest within a group cannot be determined. Although the nest mounds varied markedly in size, it is known for $F$. ulkei that there is not a simple linear correlation between nest size and age (Dreyer, 1942).

Colonies with multiple nest mounds connected via trail systems have been noted within other species of Formica (Mabelis, 1979a; Marikovsky, 1962; Skinner, 1980) and within species of other ant genera, such as Lasius and Iridomyrmex (e.g. Greenslade and Halliday, 1983; Yamauchi et al., 1981). However, the existence of permanent trails is not a prerequisite for exchange of workers among mounds. Crossover of workers among mounds occurs in the 
absence of trails in $F$. opaciventris (Scherba, 1964) and at times when apparently temporary trails are formed in $F$. ulkei (Talbot, 1961). When trails do exist in polydomous colonies they seem to function both as pathways for worker movement among nests and to foraging areas. Trail patterns may also be correlated with the shape of a colony's territory both in Formica (Mabelis, 1979b; Skinner, 1980) and other ants (Hölldobler, 1974, 1976) and, thus, be a product of both resource distribution and interactions among neighboring colonies. Habitat heterogeneity influences trail pattern, when the workers construct trails to avoid or cross unused areas of habitat (Reyes, 1986) and when features, such as roads or railway beds, define the pattern of usable habitat. The trail patterns observed in the present study suggest that habitat heterogeneity and the distribution of nests and Homoptera bearing plants influence trail location.

\section{SUMMARY}

Workers of the ant Formica obscuripes Forel, at a site in southwestern Montana, used a system of trails to travel between different nest mounds and between nests and foraging areas (primarily patches of plants bearing honeydew secreting Membracidae and Aphididae). Different groups of nests, served by non-overlapping systems of trails, apparently constituted polydomous colonies. Movement of workers among mounds was non-random both within and between nest groups. In a mark-recapture study, 97\% of the workers recaptured on nests other than those on which they were marked were found on mounds within the same trail system. Experiments in which workers were transferred between mounds demonstrated that ants tolerated workers from mounds within their own nest group, but usually acted aggressively towards workers from other nest groups. The trail patterns remained stable during the three-month study and connected nests up to $135 \mathrm{~m}$ apart. The results are compared to those obtained in other studies of Formica.

\section{ACKNOWLEDGMENTS}

This work was supported by the Montana Agricultural Experiment Station (grant MONB-155). Ronald Lang, Montana State University, determined the ant species and J. P. Kramer, Systematic Entomology Laboratory, U.S.D.A., Beltsville, Maryland deter- 
mined the Membracidae. Ruth O'Neill, Daniel Bartell, Howard E. Evans, Michael Ivie, William P. Kemp, Wendell Morrill, and Randall Ryti provided comments on the manuscript. Contribution No. J-2086 from Montana Agric. Exp. Sta.

\section{REFERENCES}

Brian, M. V. 1983. Social Insects: Ecology and Behavioural Biology. Chapman and Hall, London. vii +377 pp.

DREYER, W. A. 1942. Further observations on the occurrence and size of ant mounds with reference to their age. Ecology, 23: 486-490.

Greenslade, P. J. M. AND R. B. Halliday. 1983. Colony dispersion and relationships of meat ants Iridomyrmex purpureus and allies in an arid locality in South Australia. Insectes Sociaux, 30: 82-99.

HölLDOBLER, B. 1974. Home range orientation and territoriality in harvesting ants. Proceeding of the National Academy of Sciences, 71: 3274-3277.

HölLDOBLER, B. 1976. Recruitment behavior, home range orientation, and territoriality in harvester ants (Pogonomyrmex). Behav. Ecol. Sociobiology. 1: 405-523.

Hölldobler, B. AND C. J. LumSDen. 1980. Territorial strategies in ants. Science 210: 732-739.

Levings, S. D. and J. F. A. Traniello. 1981. Territoriality, nest dispersion and community structure in ants. Psyche (Cambridge) 88: 265-320.

Mabelis, A. A. 1979a. Nest splitting by the red wood ant (Formica polyctena Foerster). The Netherlands Journal of Zoology, 9: 109-125.

Mabelis, A. A. 1979b. Wood-ant wars. The relationship between aggression and predation in the red wood ant (Formica polyctena Först.). The Netherlands Journal of Zoology, 29: 451-620.

Marikovsky, P. I. 1962. On intraspecific relations of Formica rufa L. (Hymenoptera: Formicidae). Entomological Review, Washington, 1: 47-51.

Pamilo, P. 1981. Genetic organization of Formica sanguinea populations. Behavioral Ecology and Sociobiology, 9: 45-50.

Pamilo, P. 1982. Genetic population structure in polygynous Formica ants. Heredity, 48: 95-106.

Pamilo, P., R. Rosengren, K. Vepsäläinen, K. Varvio-Aho, and B. Pisarski. 1978. Population genetics of Formica ants. I. Patterns of enzyme gene variation. Hereditas, 89: 233-248.

ReYes, J. L. 1986. Adaptability of foraging trails in Messor barbarus. Insectes Sociaux, 33: 249-257.

Ryti, R. T. AND T. J. CASE. 1986. Overdispersion of ant colonies: a test of hypotheses. Oecologia, 69: 446-453.

Scherba, G. 1964. Analysis of inter-nest movement by workers of the ant Formica opaciventris Emery (Hymenoptera: Formicidae). Animal Behaviour, 12: 508-512.

SkinNer, G. J. 1980. Territory, trail structure and activity patterns in the woodant, Formica rufa (Hymenoptera: Formicidae) in Limestone woodland in northwest England. Journal of Animal Ecology, 49: 381-394. 
Talbot, M. 1961. Mounds of the ant Formica ulkei at the Edwin S. George Reserve, Livingston County, Michigan. Ecology, 42: 202-205.

Wallis, D. I. 1962. Aggressive behaviour in the ant, Formica fusca. Animal Behaviour, 10: 267-274.

Weber, N. A. 1935. The biology of the thatching ant, Formica rufa obscuripes Forel, in North Dakota. Ecological Monographs, 5: 165-206.

Wilson, E. O. 1971. The Insect Societies. Belknap Press of Harvard Unversity Press, Cambridge. $X+548$ pp.

Yamauchi, K., K. Kinomura, And S. MiYake. 1981. Sociobiological studies of the polygynic ant Lasius sakagamii. I - General features of its polydomous system. Insectes Sociaux, 28: 279-296. 

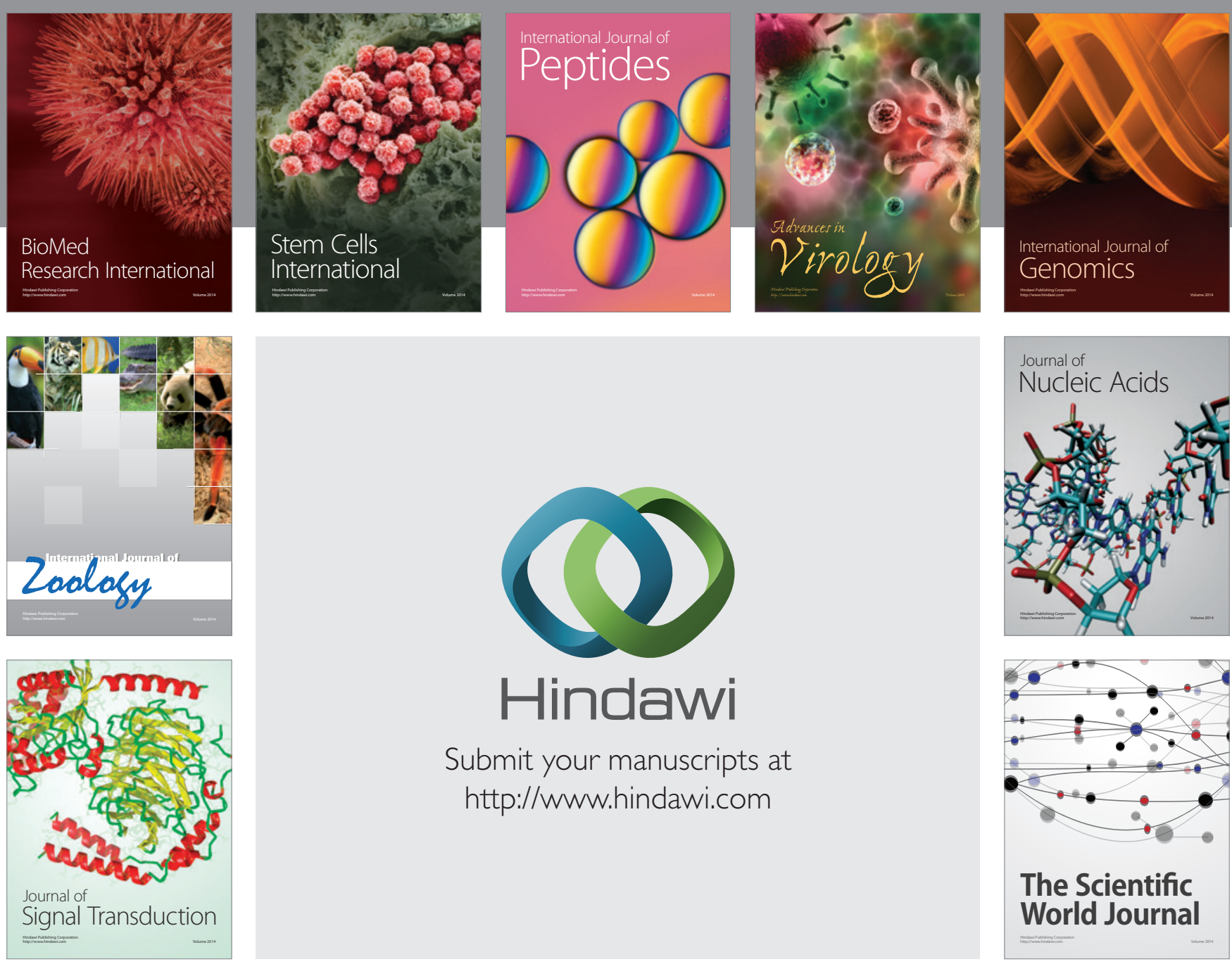

Submit your manuscripts at

http://www.hindawi.com
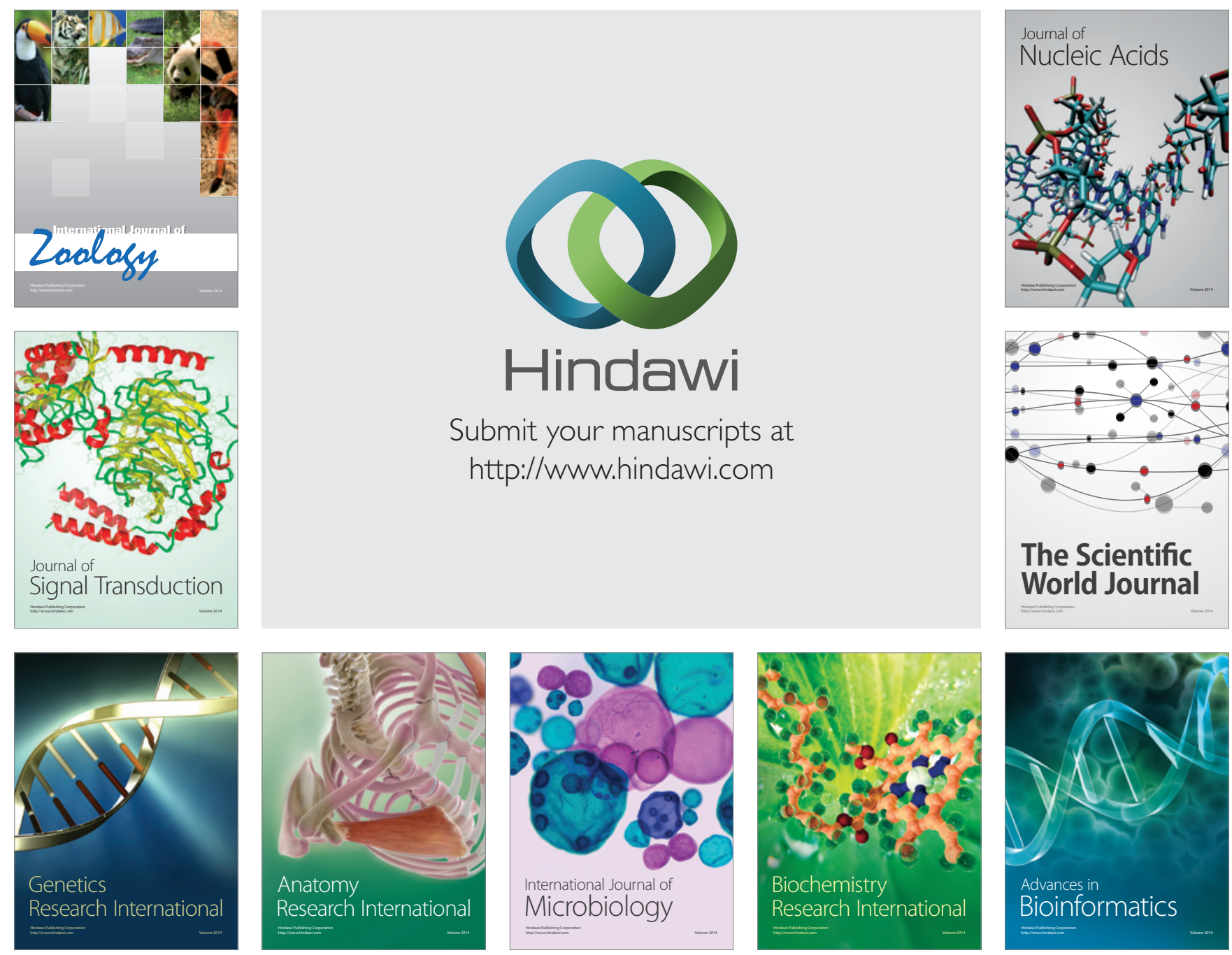

The Scientific World Journal
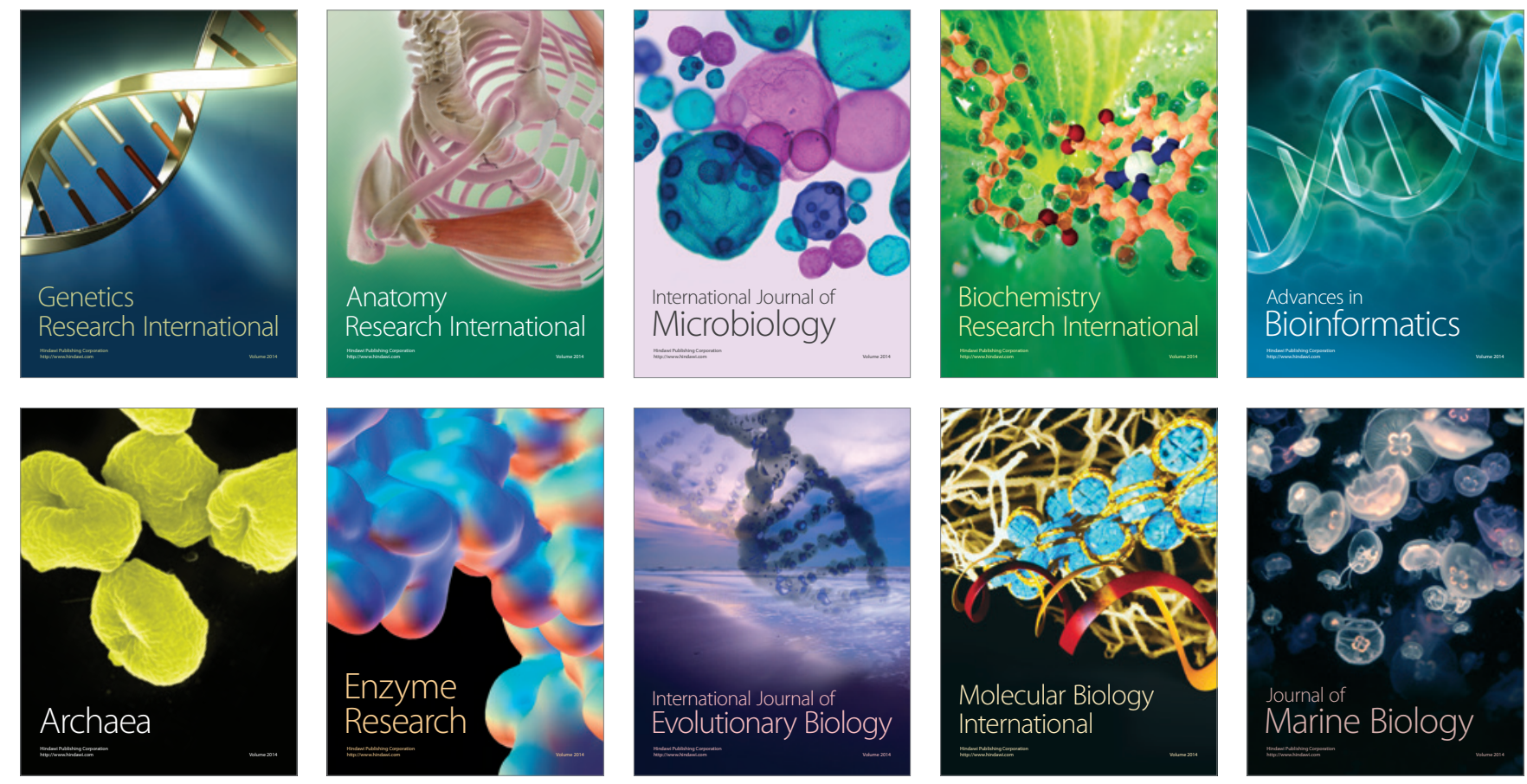